\title{
Factors that determine the sustainability of the basic sanitation service in Manizales
}

INGENIERÍA AMBIENTAL

\section{Factores que determinan la sostenibilidad del servicio de saneamiento básico en Manizales}

\author{
Isabel Castaño-Isaza ${ }^{1 \S}$ (D), María Arango-Ospina1 ${ }^{1}$, Diana Cardenas-Villamizar1(iD \\ ${ }^{1}$ Universidad Autónoma de Manizales, Facultad de Ingeniería, Master Desarrollo Regional y \\ Planificación del Territorio, Manizales, Colombia \\ §isabel.castanoi@autonoma.edu.co,maestriadedesarrollo@autonoma.edu.co,dccardenasvi@unal.edu.co
}

Recibido: 14 de agosto de 2019 - Aceptado: 24 de septiembre de 2020

\begin{abstract}
Sewage treatment is one of the great challenges in water management. In this regard, $80 \%$ of wastewater is discharged into water sources without any treatment, thus ignoring the fundamental right of access to water and sanitation and its implications for the well-being and development of populations. Colombia since the 50's began the strategy of improving water and sanitation. Seven decades of design and implementation of policies in favor of the expansion of coverage in aqueduct, sewerage and sanitation services, with significant advances for aqueduct and sewerage services and with great challenges facing the need to focus and optimize efforts to be more efficient and make the sanitation. The study and understanding of sustainable basic sanitation was carried out through the search for secondary information carried out in sectoral reports and research documents, where factors that positively or negatively affected the provision of the sanitation service were identified. On the other hand, the understanding of the social and political dynamics of the territory allows in the context of the city of Manizales to identify and analyze the perceptions from the three pillars of sustainability, natural environment, social environment and economic environment of two interest groups in the company Aguas de Manizales SA ESP, provider of the aqueduct and sewerage service in the city, through the application of a user survey and the carrying out of focus groups with institutions and community leaders. Lastly, solutions and strategies are proposed that eliminate causes or reduce the impacts that make it impossible to consolidate the public sanitation service or to maintain it over time.
\end{abstract}

Keywords: Basic sanitation, Citizen participation, Public service, Sustainable cities, Sustainable development.

\section{Resumen}

El tratamiento de las aguas servidas representa uno de los grandes desafíos en la gestión del agua. Al respecto, el $80 \%$ de las aguas residuales son vertidas a las fuentes hídricas sin ningún tipo de tratamiento, desconociendo de esta forma el derecho fundamental del acceso al agua y al saneamiento y sus implicaciones el bienestar y desarrollo de las 
poblaciones. Colombia desde la década de los 50's inicia la estrategia de mejoramiento del agua y el saneamiento. Siete décadas de diseño e implementación de políticas a favor de la ampliación de las coberturas en servicio de acueducto, alcantarillado y saneamiento, con avances significativos para los servicios de acueducto y alcantarillado y con grandes retos frente a la necesidad de focalizar y optimizar los esfuerzos para ser más eficientes y hacer más sostenible el saneamiento. El estudio y entendimiento del saneamiento básico sostenible se realizó a través de la búsqueda de información secundaria realizada en informes sectoriales y documentos de investigación, donde se identificaban factores que incidían de forma positiva o negativa en la prestación del servicio de saneamiento. Por otra parte la comprensión de las dinámicas sociales y políticas del territorio permite en el contexto de la ciudad de Manizales identificar y analizar las percepciones desde los tres pilares de la sostenibilidad, medio natural, medio social y medio económico de dos grupos de interés de la empresa Aguas de Manizales S.A E.S.P, prestadora del servicio de acueducto y alcantarillado en la ciudad, a través de la aplicación de encuesta a los usuarios y de la realización de unos grupos focales con instituciones y líderes comunitarios.

Los resultados de la investigación aportaron elementos importantes para la toma de decisiones informadas a la empresa Aguas de Manizales S.A E.S.P que pueden ser consideradas por otras ciudades de similares características que deseen implementar de manera sostenible el servicio de saneamiento básico.

Palabras clave: Ciudades sostenibles, Desarrollo sostenible, Participación ciudadana, Saneamiento básico, Servicio público.

\section{Introduction}

Manizales, located in the coffee region of Colombia, has a population for the year 2018 according to information from DANE of 400,436 inhabitants, of which $93.8 \%$ inhabit the urban area formed according to decree 0042 of February 28, 2005 by 11 communes and 114 neighborhoods. In 2012, it became part of the Sustainable Cities program of the InterAmerican Development Bank - IDB. In coherence with the above, from the green standards congress held in the city in 2017, the determination is made to advance in programs and projects that ensure their environmental sustainability, making the decontamination of rivers and streams one of the great challenges.

The provision of sanitation services in the city are under the responsibility of the company Aguas de Manizales S.A. E.S.P., which reports 112,582 aqueduct subscribers with coverage as of June 2019 of $99.98 \%$ and 107,747 in sewerage with coverage of $99.03 \%$. The great gap in the city is related to the lack of wastewater treatment, making the construction of the WWTP Wastewater Treatment Plant one of the great challenges of the city.
Providing a complete sanitation in the city of Manizales implies an increase in water and sewerage service rates for users; In this sense, it was considered to inquire from the perspective of users and based on the sustainability criteria of this type of project, what are their conceptions about wastewater treatment and what are the daily practices from the domestic sphere that may affect negatively the operation of the plant.

A water and sanitation system is sustainable when throughout its projected life it provides the desired level of service, with criteria of quality and economic and environmental efficiency, which can be financed or co-financed by its users, with a reasonable minimum of external support and technical assistance, and that it is used efficiently without causing a negative effect on the environment ${ }^{(1)}$.

\subsection{Associated problems}

One of the great challenges in water management is associated with the treatment of wastewater. $80 \%$ of the wastewater on the planet is discharged to water sources without any treatment, directly affecting the fundamental 
right of access to water and sanitation and therefore the well-being and development of populations. In this regard, the World Health Organization (WHO) reports that the death of 361,000 children under the age of 5 can be prevented on the planet by having quality water and complete basic sanitation. Investing US \$ 1 in sanitation is equivalent to a return in benefits of US \$ 9.1 in health and therefore in productivity ${ }^{(2)}$.

According to the Andean Development Corporation (CAF), 250 billion dollars are required in Latin America and the Caribbean so that, in the year 2030, as promoted in the SDG Sustainable Development Goals, $100 \%$ coverage can be achieved for urban areas in drinking water, $94 \%$ of sewage coverage and $64 \%$ of wastewater treatment ${ }^{(3)}$.

Additionally, considering that the population that lives in the cities of developing countries tends to double between 2000 and 2030 and that such urban growth is projected mostly in small and medium-sized cities (less than one million inhabitants). as reported (4), large investments will be needed to optimize current systems and maintain the health of ecosystems.

The Superintendence of Residential Public Services (SSPD) in its technical report on wastewater treatment in the country (2014), raises the need to put into operation the plants that are out of service, and improve the aspects related to institutionality by identifying as for 2016 from the 620 treatment systems built in the country only $10 \%$ operated ${ }^{(5)}$. This is validated by the United Nations in its report on the development of water resources in 2017 , where wastewater management is characterized as expensive and with a low rate of return due to the high costs of the initial investment, operation and plant maintenance ${ }^{(2)}$.

\subsection{Background to basic sanitation}

The origin of basic sanitation dates back to the Neolithic period when humans in $6500 \mathrm{BC}$ in the Jezreel Valley dug the first water wells for the supply of their families (6); the importance of basic sanitation and the supply of drinking water is becoming greater as the size of human settlements increases; the open-air rooms, used for the final disposal of waste, represented the only alternative available for this purpose. In the ruins of Mohenjo-Daro in Pakistan, Dholavira in Kutch, and the Gujarat District in the Indus Valley, evidence of one of the most sophisticated sewage systems in the ancient world was found by incorporating drainage channels, rainwater harvesting and conduits that went to the streets (7). In the city of Lothal all the houses had their private bathroom connected to a sewer network built of brick attached to a plaster-based mortar that was emptied into the surrounding water bodies or alternatively into cesspools ${ }^{(8,9)}$.

Likewise, the ancient Greek Cretan civilization, also known as the Minoan civilization, was the first to use underground clay pipes to carry out sanitation and water supply. Their capital, Knossos, had a water system that allowed them to bring clean water, remove sewage, and evacuate water in case of high rainfall (10). Plumbing and sewerage have been used in East Asia since the Qin and Han dynasties ${ }^{(11)}$.

Roman cities and some UK cities - between 301 $\mathrm{AD}$ and $400 \mathrm{AD}$ built complex sewage networks, in some cases with hollowed out elm logs. Among its innovations, the construction of a sewerage network to collect wastewater from the cities of Rome, Istanbul (Constantinople) and Fustat stands out. The system is currently used to collect liquid waste that flows into modern wastewater treatment facilities. In the 16th century, Sir John Harington invented the first flush toilet as a device for Queen Elizabeth I, who released waste into the pits ${ }^{(12)}$. 
Cities without a sewerage system relied on brooks, nearby rivers, and occasional rains to wash wastewater that ran down the streets to flow into the nearest watershed. ${ }^{(12)}$. The system covered the needs of cities with few inhabitants, however, their growth during the industrial revolution quickly led to streets with higher levels of contamination, causing outbreaks of diseases such as typhoid and cholera during the 19th century. In cities like Merthyr Tydfil in South Wales, houses discharged their sewage into small individual ditches that persistently overflowed causing the platforms to be covered by sewage ${ }^{(13)}$. In response, in the period between the end of the 19th century and the beginning of the 20th century, the construction of extensive sewerage systems began ${ }^{(14)}$.

In the 19th century, the River Thames was the open drain to which all household and industrial waste arrived; Due to growing diseases, it was proposed to modernize the sanitation system and it was only until the time of the "Great Stink" of 1858 that the British Parliament realized the need to modernize the sewer system ${ }^{(14)}$.

John Snow in his eagerness to know the origin of the cholera, cause of deaths in London, discovered that in South London, where the most deaths occurred, they drank water from the lower part of the River Thames, the section with the highest level of contamination and from this finding, he validated his hypothesis that cholera was produced by the ingestion of a "morbid matter" present in the water of the River Thames as a result of depositions made there directly or through improvised sewers ${ }^{(15)}$.

In the United States of America, residential wastewater management in the 17 th century consisted primarily of discharge of waste, usually into the backyard, street, gutter, or open canal. Due to the low population densities at the time, the majority of the inhabitants accepted sanitation problems as something necessary and as part of urban life, especially in New York, and it was only considered a real problem with the appearance of epidemics ${ }^{(14)}$. These practices were gradually and simultaneously changing in the 18th century with European systems and environmental sanitation systems were associated with the development of a city. With the emergence of the concept of sustainable development and water as a human right, the improvement of water and sanitation conditions begins.

Starting in 1974, at the Cocoyoc Mexicomeeting (1) there was a debate about separating the concepts of development and growth, and addressing a more comprehensive position that accounts for human beings as subjects of development in a framework of sustainable development that makes a call about the existence of a limit. Under this concept it is argued that the problems are not only of the technological order, they must be posed in articulation with the community and the environment as reported in the Figure 1, where the area of confluence between the three components represents the space where it is possible to minimize risks that arise in water contamination given the possibility of generating a citizen culture that is reflected in the change of habits within the household that tend to improve the quality of the service, within a legal, political and institutional framework.

Faced with the search for solutions in water and sanitation development programs, express that the water and sanitation service is not only infrastructure, it must be viewed at with an integrating vision, where there are important components such as the community and its organization, environmental conditions, technological options, all within a legal, political and institutional framework influenced by macroeconomic conditions ${ }^{(1)}$. 


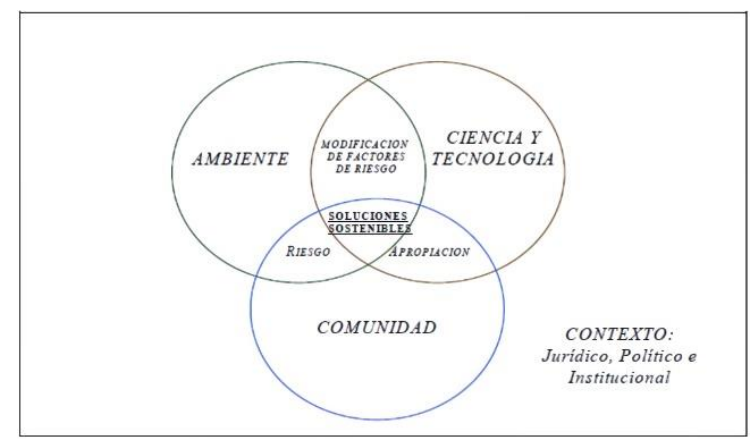

Figure 1. Sustainable Water and Sanitation System ${ }^{(1)}$

Sustainability in the management of wastewater sanitation has several dimensions that depend on and support each other. For the system to be sustainable, it must be it in all dimensions and taking into account the context. These authors express that the logic is the recovery of the resources contained in the wastewater ${ }^{(4)}$. For its part, the Alliance for Sustainable Sanitation (SuSanA) cited by Kim Andersson at al. ${ }^{(4)}$, defines sustainable sanitation from five Dimensions: health, institutional and social, technical, financial, and environmental as recorded in Figure 2.

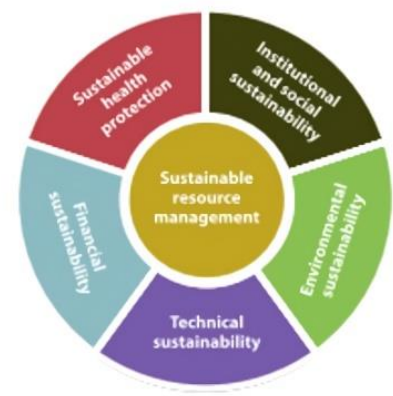

Figure 2. Dimensions of sustainability in sanitation and wastewater treatment: Stockholm Environmental Institute $^{(4)}$

\section{Methodology}

It corresponds to a mixed descriptive and interpretive research with a correlational scope. Starting from an exercise of identification, systematization and analysis of information from different sources. The information obtained from these documents was systematized in a consolidation matrix where it was organized by categories in correspondence with the criteria that guarantee the sustainability of the WWTPs.

This information was counteracted with the information generated from the perceptions of the stakeholders of Aguas de Manizales S.A. E.S.P. ${ }^{(16)}$, prioritized taking into account the degree of relationship with the company; The users of the service were linked through a survey applied to 400 of the subscribers, designed with 38 questions grouped into five blocks: basic and billing information, housing and the home, environmental sanitation, willingness to pay for the service and political-institutional information (participation). The selection of the sample was carried out randomly with the help of Excel, taking into account the proportion according to the socioeconomic stratum, as observed in Table 1 . It is reported by the distribution of users in the city grouped by strata for a total of 96,252 subscribers. The sample was calculated through Eq. 1.

Table 1. Percentage of residential users by stratum

\begin{tabular}{lcc}
\hline $\begin{array}{c}\text { Class of } \\
\text { service }\end{array}$ & Subscribers & $\begin{array}{c}\text { Representation } \\
\text { percentage }\end{array}$ \\
\hline Stratum 1 & 8,725 & 9 \\
Stratum 2 & 19,881 & twenty-one \\
Stratum 3 & 36,317 & 38 \\
Stratum 4 & 15,749 & 16 \\
Stratum 5 & 5,664 & 6 \\
Stratum 6 & 9,916 & 10 \\
Residential & 96,252 & 100 \\
total & & \\
\hline$N=\frac{Z^{2} P Q N}{N E^{2}+Z^{2} P Q}$ & & $($ Eq. 1$)$
\end{tabular}

$\mathrm{N}$ : Universe

E: Error

N: Sample size 


\section{Z: Confidence level}

Q: Probability in favor

Q: Probability found

For a $95 \%$ confidence level, there is a value of $\mathrm{z}$ $=1.96$ and a probability for and against 0.5 .

In total 400 surveys were carried out, which were applied to users distributed in the city from a stratified random sampling. The survey was answered by one of the users of the service in the selected dwellings; the inclusion criteria was to be of legal age.

The systematization and analysis of the information was carried out through Excel and the SPSS software version 25. The information collected from the focus groups was also analyzed through a relationship matrix, in order to determine the factors identified by the different groups. As sources of information, information available in specialized databases on the study area such as Science Direct, SciELO, Scopus, institutional reports, documents from multilateral organizations, documentation from public entities, newspapers, among others, that reported experiences both at the level of Colombia and other countries was considered. This information was systematized by categories associated with the sustainability criteria of the basic sanitation system in a relationship matrix.

Information from the survey related to the willingness to pay for the service block and political-institutional information (participation) inquired about aspects related to users' desire to pay, knowledge about issues related to wastewater, culture of care for natural resources, participation in activities with the municipal administration, among others.

Additionally, three focus groups were carried out in order to collect primary information, through a series of guiding questions that allowed identifying their perceptions about the basic sanitation service - wastewater treatment in the city of Manizales and the construction of a wastewater treatment plant in the Cámbulos sector. These are recorded in Figure 3.

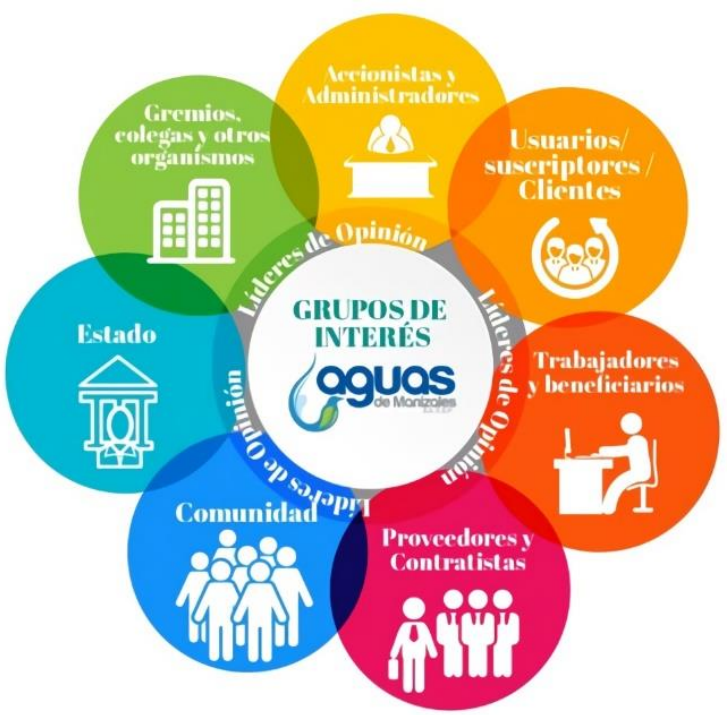

Figure 3. Interest Groups - Aguas De Manizales SA $\operatorname{ESP}^{(16)}$

The following Figure 4 describes the community interest group and Figure 5 describes the State interest group.

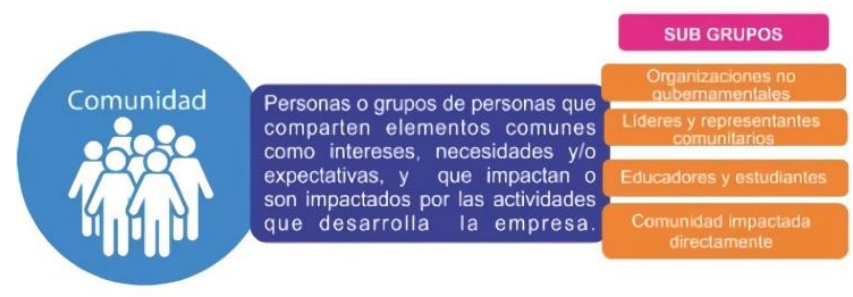

Figure 1. Community Interest Group: Aguas De Manizales SA $\operatorname{ESP}^{(16)}$

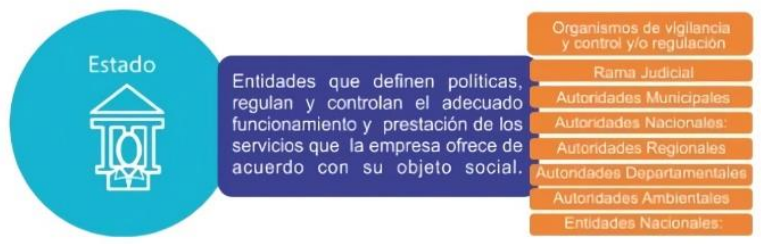


Figure 2. State Interest Group: Aguas De Manizales $S A \operatorname{ESP}^{(16)}$

Considering the competencies and functions of the groups associated with the State, they were divided into State institutions, the community and the control entities, thus forming the groups with which the focus group technique was implemented as reported in Table 2 .

\section{Table 2. Focus groups}

\begin{tabular}{ll}
\hline Interest group & Who belong \\
\hline \multirow{4}{*}{ Institutions } & Environmental authority - \\
& Corpocaldas. \\
& Manizales City Hall \\
& Caldas Governorate \\
& Leaders \\
& Community action boards \\
& Local action boards \\
& Sewer service users \\
Community & Development and social \\
& control committees \\
& Control vowels \\
& Personería \\
& Comptroller \\
& Attorney \\
& Ombudsman \\
\hline
\end{tabular}

\section{Results and Discussion}

As a basis for the research, factors of a social, economic, political, institutional, technical, contextual and natural that affect the implementation of the basic sanitation service in the city of Manizales were defined, which were analyzed, among others, from information supplied by the sources described. For research purposes, "the factor" is defined as that from which results are produced and, therefore, has a great weight in the variability of the changes. In the case of sustainable sanitation, a variety of factors were identified, over which an entity may or may not have control, but which, when identified facilitate its management.

From the documentary review 147 factors were identified and subsequently, a reduction of data was carried out, grouping them by units. The criteria for carrying out the separation was thematic considering the categories and variables with the highest recurrence identified during the research. The categories identified were economic, natural, social, technical, political, institutional and contextual. Once the factors are in each of these, the search for relationships between them begins and they are grouped by category. The result of the process allowed the construction of the scheme represented in Figure 6.

The result of the identification of the factors from the secondary information showed a great incidence of the social dimension; This was validated through the perception of potential users regarding the sanitation project from the different categories. $71 \%$ of the people who answered the survey were between 45 and 65 years old and by socioeconomic stratum they are distributed as follows: 9\% stratum 1, 21\% stratum 2, 38\% stratum 3, $16 \%$ stratum $4,6 \%$ stratum 5 and $10 \%$ for stratum 6 . Regarding the educational level, the secondary level is equivalent to $37 \%$, followed by $29 \%$, which represents the university level, the technical level in $17 \%$ and primary level with $15 \%$.

One of the incident factors in the sustainability of the service is knowledge about basic sanitation, for this purpose, the population was inquired if they knew what a wastewater treatment plant is. The answers were related to the socioeconomic strata and the educational level of the interviewees with the results presented in Figure 7 and 8. 

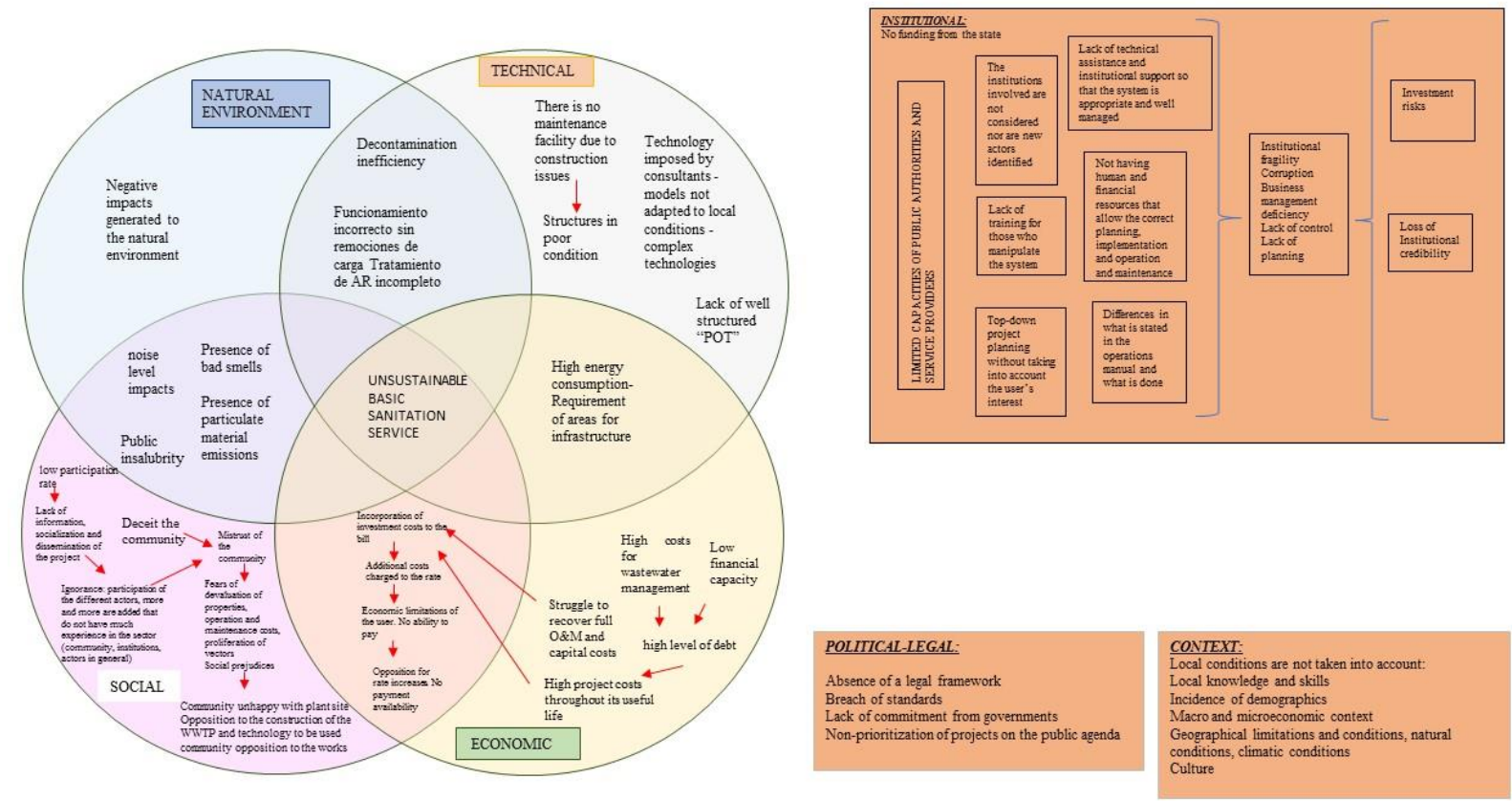

Figure 6. Factors that restrict the sustainability of the sanitation service

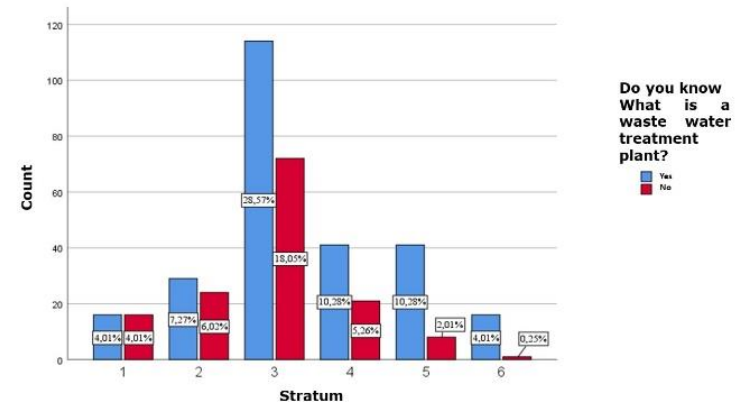

Figures 7. Knowledge question - stratum

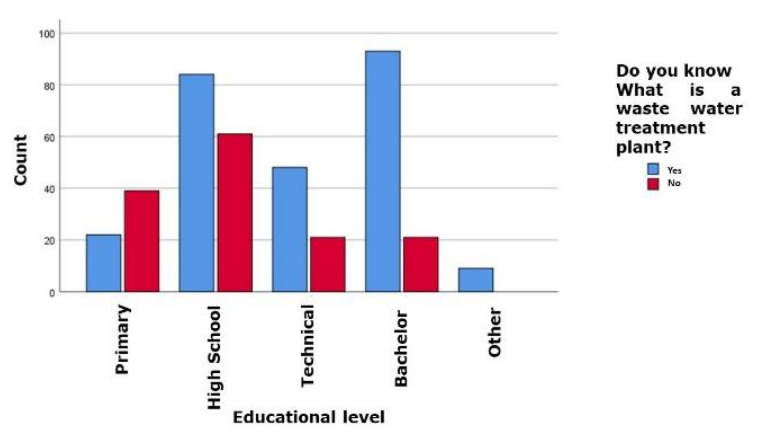

Figures 8. Question about knowledge - educational level

The results show a direct relationship between the educational level, the stratum and the level of knowledge. From the economic component, the amount that people would be willing to pay for water decontamination was inquired. The results are presented in Figure 9.

Subsequently, the reasons for not paying for the service are investigated, identifying as it is reported in Table 3, that $61 \%$ are of an economic nature.

Table 3. Observation of non-willingness to pay

\begin{tabular}{lc}
\hline $\begin{array}{c}\text { Responses for availability } \\
\text { of payment \$ 0 }\end{array}$ & $\begin{array}{c}\text { \% In } \\
\text { response }\end{array}$ \\
\hline Increase the price of services & 11 \\
Very high service costs & 27 \\
You do not know the procedure thoroughly & 5 \\
Optimal service is not provided & 1 \\
It must be paid by the state or the lending & 23 \\
company & 32 \\
Economic situation & \\
\hline
\end{tabular}

Given that the operation and maintenance of a WWTP represents one of the most important factors in the service fee and that its value depends, among other factors, on the prevention 
of contamination due to the effect of discharges to the plant, respondents were asked about good practices of the final disposal of some products for everyday use at home. The results are reported in the Table 4.

Would you be willing to pay additionally to your monthly aqueduct and sewer bill so that the utility company treats the wastewater, contributes to improving the environment and helps the city not receive the unhealthy effects of untreated sewage?

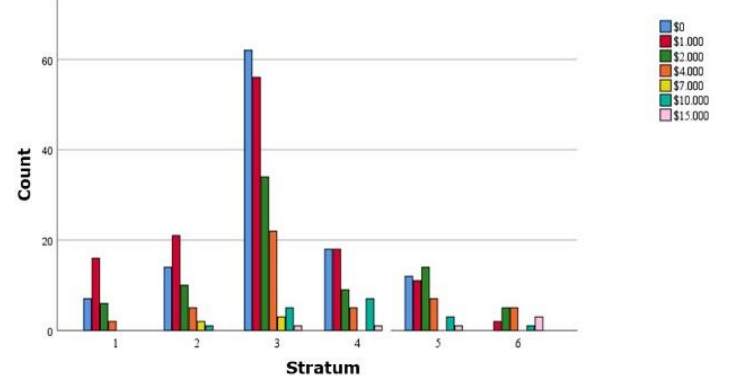

Figures 9. Payment availability

In this regard, it is highlighted how, from the exercise of the focus groups, it was identified that there are no good practices from homes.

Regarding the institutional political category, the answers allow us to conclude that Aguas de Manizales S.A. E.S.P. has a good image and there is trust towards the company. However, it was identified that the community in general does not participate in meetings related to municipal administration and less than 10\% respond positively to this type of call.

The triangulation of information from different sources, including that obtained from visits to similar projects at the national and international level, allows us to conclude that the factors reported in the documentary sources apply in the case of the city of Manizales, to a greater or lesser extent. lower proportion. The findings allow the design of an intervention strategy, as presented in Figure 10, that considers the identified factors and their interaction from the dimensions, framed in institutional politics, and the context of the city as a condition for the provision of a sustainable sanitation service in the city of Manizales that progress towards achieving the following objectives:

Goal 1: Safe, healthy and sustainable habitat.

Goal 2: Technology adapted to the region,

Table 4. Use of waste in the home

\begin{tabular}{|c|c|c|c|c|c|c|}
\hline Object & Wet wipes & $\begin{array}{l}\text { Cotton } \\
\text { swabs }\end{array}$ & $\begin{array}{c}\text { Dental } \\
\text { floss or } \\
\text { floss }\end{array}$ & Waste oil & $\begin{array}{l}\text { Food } \\
\text { waste }\end{array}$ & $\begin{array}{l}\text { Toilet } \\
\text { paper }\end{array}$ \\
\hline Trash & 393 & 392 & 396 & 285 & 380 & 359 \\
\hline Sanitary & & & 3 & 3 & 2 & 35 \\
\hline Hand wash & & & & 6 & & \\
\hline Dishwasher & & & & 39 & 6 & \\
\hline Other & 4 & 1 & & 62 & 11 & 2 \\
\hline \multirow[t]{2}{*}{ No data } & 1 & 7 & 1 & 5 & 1 & 4 \\
\hline & Hair & $\begin{array}{c}\text { Sanitary } \\
\text { towels }\end{array}$ & Tampons & Condoms & $\begin{array}{c}\text { Cigarette } \\
\text { butts }\end{array}$ & $\begin{array}{c}\text { Candy } \\
\text { packaging }\end{array}$ \\
\hline Trash & 388 & 390 & 386 & 380 & 302 & 394 \\
\hline Sanitary & 6 & & 1 & 5 & one & \\
\hline Hand wash & 1 & & & & & \\
\hline \multicolumn{7}{|l|}{ Dishwasher } \\
\hline Other & 2 & 1 & 4 & 3 & 30 & 4 \\
\hline No data & 3 & 9 & 9 & 12 & 67 & 2 \\
\hline
\end{tabular}


complying with decontamination parameters.

Goal 3: Payment capacity and availability.

Goal 4: Promote water governance by guaranteeing the strengthening, active and inclusive participation of all actors, of the legal tools available at the different levels of government and within the context of the region.

\section{Conclusions}

Once the objectives have been outlined and the search for information has begun, there is a shortage of it, especially at the national level, which implies difficulty in the construction of clear public policies focused on solving the problem.

According to the views of the referring authors, it can be concluded that the basic sanitation service is not just about infrastructure. In order for it to be sustainable, the decontamination objectives to be achieved must be clear, according to the characteristics of the wastewater generated, the appropriate technologies for meeting the decontamination objective against social acceptance and maintenance costs, review it in relation to the location and land available for the construction of the WWTP, demography, behavior and social culture, climatic factors, availability and ability to pay users, political and institutional commitment, available financial resources and the actors involved. Likewise, it is necessary to guarantee a process of training and capability building at all levels and according to the competencies for both, those who manage the service and for its users.

According to CONPES 3177 the costs of construction, operation and maintenance of a wastewater treatment system can increase the rate by $39.6 \%$, likewise, if the investment costs are covered with different sources, the rate can be increased by $33 \%$ since the operation and maintenance costs must be recovered as required by Public Services Law 142. This same Law grants the benefit of subsidy to strata 1,2 and 3 and requires strata 5 and 6 to make a

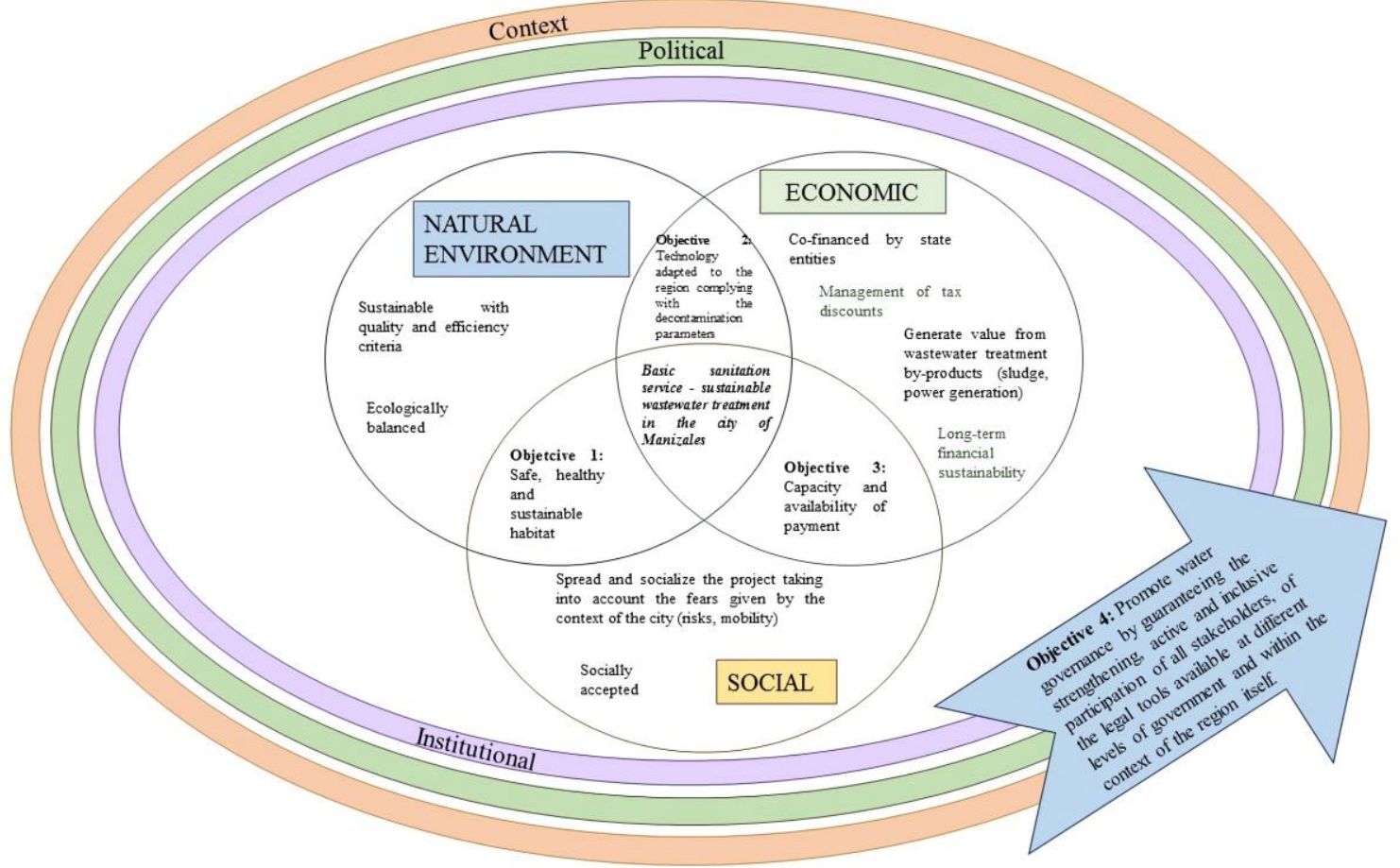

Figure 10. Intervention proposal 
contribution to execute these. For the specific case of the city of Manizales, it was identified that stratum 3 is the most representative and stratum 6 the least. Taking into account that strata 1, 2 and 3 are those who present the greatest difficulty in paying for public services according to the surveys carried out,

It is necessary to carry out a deeper analysis in order to ratify this information and take the necessary corrections.

As the literature expresses one of the factors for which some initiatives have failed to sustain the sanitation service, is the institutionality, seen from the point of view of political will, support for the initiative, creation of policies for reduction and control pollution, but also requires the strengthening of different actors to face this new service. It is striking that people in the most remote neighborhoods of the industrial zone consider that it is the industry that pollutes the Chinchiná river; Another group of people stated that the wastewater comes from rainwater and that from the focus groups it is concluded that there is a bad disposal of waste at home, despite their responses, situation that calls for the lack of awareness regarding their responsibility in terms of the contribution that each one makes to pollution and also the level of co-responsibility that each one has in terms of decontaminating.

The social dimension takes on importance in the sustainability of the sanitation service, bearing in mind that they are the ones who benefit, but they are also the ones who will pay for the new service to be provided. They are the key link to give continuity to the operation and maintenance of the system; however, managing to cover expenses also depends on training and installing skills in those who administer, control and operate the system.

Implementing the new basic sanitation service in the city of Manizales, contributes to the decontamination of the Chinchiná river basin, improves the quality of life of the inhabitants by reducing the impacts generated by the contaminated river, improving public health and health indicators equality in terms of access to the constitutional right to a healthy environment.

Plan the basin taking into account the ecological principles of the natural system, recognizing culture, history, promoting the participation of society and institutions to carry out collective actions with a long-term vision and projecting Manizales as a sustainable city.

\section{Recommendations}

Taking into account that $33 \%$ of the rate increase for sanitation service is due to operation and maintenance, it is necessary for the company to design and adopt operating manuals for the WWTP, as well as to carry out controls, followup and adjustments to minimize costs. Also train the required personnel. As expressed by UNESCO, one of the shortcomings in developing countries in sustaining these systems is low institutional capacity. Likewise, given that the decrease in pollution in wastewater from generation significantly reduces the costs of operation and maintenance, an environmental education program is necessary, as well as the implementation of public policy regarding the issue of wastewater treatment.

\section{Funding Statement}

The author(s) received no specific funding for this work.

\section{References}

(1) CINARA, Servicios Publicos Domiciliarios, FINDETER. Servicios sostenibles de agua y saneamiento : marco conceptual. 1998;157 p.: 10 fig., 20. Available from: http://www.ircwash.org/sites/default/files/ 827-CO-15345.pdf.

(2) WWAP (United Nations World Water 
Assesment Programme). The United Nations World Water Development Report 2017: Wastewater the untapped resource. UNESCO. Paris; 2017.

(3) Mejía A, Requena B, Rivera D, Pardón M, Rais J. Agua potable y saneamiento en América Latina y el Caribe: Metas realistas y soluciones sostenibles. 1st ed. Corporación Andina de Fomento (CAF), editor. Panamá; 2012.56 p.

(4) Andersson K, Dickin S, Rosemarin A. Towards "Sustainable" Sanitation: Challenges and Opportunities in Urban Areas. Sustainability. 2016;8(12):1289. https://doi.org/10.3390/su8121289.

(5) Superservicios. Informe Técnico sobre Sistemas de Tratamiento de Aguas Residuales en Colombia. Bogotá, D.C.; 2014.

(6) Ashkenazi E. Ancient Well Reveals Secrets of First Jezreel Valley Farmers. Haaretz [Internet]. 2012 Nov 8. Available in: https://www.haaretz.com/one-ofworld-s-oldest-wells-found-in-israel1.5197284 .

(7) Mughal M. Mohenjo-daro's Sewers. World History Encyclopedia - Vol. 3. McGeough KM, editor. Santa Barbara, CA; 2011. 121-122 p.

(8) Khan S. Sanitation and wastewater technologies in Harappa/Indus valley civilization (ca. 2600-1900 BC). In: Angelakis A, Rose J, editors. Evolution of Sanitation and Wastewater Technologies through the Centuries. 1st ed. London: IWA Publishing; 2014. p. 25-42.

(9) Messer, A. Maya plumbing, first pressurized water feature found in New World. Penn State [Internet]. 2010 May 5. [consulted 2014 March 26]. Available in: https://news.psu.edu/story/141704/2011/0 2/08/research/maya-plumbing-firstpressurized-water-feature-found-newworld.

(10) Teresi D. Lost Discoveries: The Ancient Roots of Modern Science--from the Babylonians to the Maya. 1st ed. Simon \& Schuster Paperbacks, editor. New York; 2003. 464 p.

(11) Chavalas MW, editor. Great Events from History: The Ancient World Prehistory 476 C E. Pasadena: Salem Press; 2004. $545 \mathrm{p}$.

(12) Schladweiler J, McDonald J. Schladweiler JC, McDonald J. 1300's - Late 1500's Sir John Harington's New Ajax (The True Roots of the Modern Day Flush Toilet) with Impetus Provided to John Harington by Queen Elizabeth, "The Schoole of Salerne", and "The Englishmans Doctor." London; 2004.

(13) Glamorgan County Council. Report of the Principal Officer of Health. Glamorganshire, Wales; 1889.

(14) Burian SJ, Nix SJ, Pitt RE, Durrans SR. Urban Wastewater Management in the United States: Past, Present, and Future. J Urban Technol. 2000;7(3):33-62. https://doi.org/10.1080/713684134.

(15) Cerda J, Valdivia G. John Snow, the cholera epidemic and the foundation of modern epidemiology. Rev chil infectol. 2007;24(4):331-4. http://dx.doi.org/10.4067/S071610182007000400014.

(16) Aguas De Manizales SA ESP. Grupos de interés [Internet]. Manizales: Aguas De Manizales SA ESP, editors; [Revised 2020 sep 25]. Available from: https://www.aguasdemanizales.com.co/Nu estraEmpresa/InformacionGeneral/Entidad esAgremiaciones\#seccion748. 
